\title{
Edukasi dan Sosialisasi Pencegahan dan Pengendalian COVID-19 melalui Media Poster di Desa Bojongsoang, Kabupaten Bandung
}

\author{
Dino Caesaron, Sheila Amalia Salma, Murman Dwi Prasetyo, Mohammad Husain Rifai \\ Departemen Teknik Industri, Fakultas Rekayasa Industri, Universitas Telkom \\ Jl. Telekomunikasi, Terusan Buah Batu, Bandung, 40257, Indonesia
}

\begin{abstract}
ARTICLE INFO
Received: 2019-05-24

Revised: 2019-10-19

Accepted: 2020-01-18

Keywords:

Clean and healthy living behavior, COVID19, Education, Health protocol, Socialization
\end{abstract}

\begin{abstract}
The COVID-19 virus has infected many people, resulting in death tolls around the world. So, it is necessary to adopt a clean and healthy lifestyle and implement health protocols such as using masks, washing hands and maintaining distance. This community service activity aims to provide education and assistance to community representatives in Desa Bojongsoang, Bandung, to always implement a healthy and clean lifestyle and health protocols. Educational activities are carried out by providing counseling with the methods of lectures, discussions, and questions and answers. Material delivery is also conveyed through the media of posters, so that the posters can be affixed to strategic areas so that it can be seen and read effectively. In this activity, an evaluation of the level of community compliance in implementing health protocols while outside the home was also carried out, by distributing questionnaires before the activity took place. As a result, in general the community is disciplined in applying health protocols while outside the home. Several findings were also obtained in this simple survey, so that these findings can be used as initial data/information for local stakeholders to streamline education and socialization in efforts to prevent the massif transmission of the COVID-19 virus.
\end{abstract}

(C) 2021 Published by University of Merdeka Malang. This is an open access article distributed under the CC BY-SA 4.0 license (https://creativecommons.org/licenses/by-sa/4.0/)

How to cite: Caesaron, D., Salma, S. A., Prasetyo, M. D., \& Rifai, M. H. (2021). Edukasi dan Sosialisasi Pencegahan dan Pengendalian COVID-19 melalui Media Poster di Desa Bojongsoang, Kabupaten Bandung. Abdimas: Jurnal Pengabdian Masyarakat Universitas Merdeka Malang, 6(2), 221-229. https://doi.org/10.26905/abdimas.v6i2.5354

\section{PENDAHULUAN}

Coronavirus Disease 2019 atau yang lebih dikenal dengan COVID-19 merupakan jenis baru dari virus Corona yang diberi nama Severe Acute Respiratory Syndrome Coronavirus 2 (SARS-CoV-2) (Gorbalenya et al., 2020). Virus ini diidentifikasikan pertama kali di Kota Wuhan, Cina, pada akhir tahun 2019 (Evans, 2020) yang menyerang sistem pernapasan manusia baik anak-anak hingga dewasa dan orang tua (Anhusadar, 2020). 
ABDIMAS: Jurnal Pengabdian Masyarakat Universitas Merdeka Malang Volume 6, No. 2, May 2021: 221-229

Virus ini dapat menular secara mudah melalui droplet (percikan) yang keluar pada saat berbicara, bersin, dan batuk dari orang yang terinfeksi virus COVID-19. Selain itu, virus ini juga dapat menular melalui kontak erat dengan konfirm positif COVID-19, seperti sentuhan fisik secara langsung; bersalaman, berpegangan tangan, dan lain-lain (Singhal, 2020).

Gejala gangguan kesehatan yang biasanya muncul jika terinfeksi virus ini seperti flu biasa, batuk, pilek, demam diatas 37,50C hingga gejala komplikasi berat seperti, sesak nafas dan pneumonia hingga dapat menyebabkan kematian yang biasanya disertai dengan penyakit kronis bawaan seperti kardiovaskular dan diabetes (Huang et al., 2020). Tanda lainnya pada organ vital umumnya terlihat stabil, namun jika dilakukan tes darah biasanya menunjukkan jumlah sel darah putih (leukopenia dan limfositopenia) yang relatif rendah (Hui et al., 2020). Selain gejala gangguan kesehatan yang terlihat, sebagian kasus seringkali menunjukkan tanpa gejala atau yang lebih dikenal dengan Orang Tanpa Gejala/OTG (Zimmermann \& Curtis, 2020).

Jumlah kasus suspek, kasus probable, kontak erat, dan kasus konfirmasi positif COVID-19 di seluruh Indonesia semakin bertambah temasuk wilayah Jawa barat, khususnya Kabupaten Bandung. Data yang diambil dari Pusat Informasi \& Koordinasi COVID-19 (2020) pemerintah Jawa Barat dan Satuan Tugas Penanganan COVID-19 Republik Indonesia (2020), terdapat 18.638 kasus baru yang terkonfirmasi positif COVID-19 dengan 7.343 (4,3\%) orang yang terkonfirmasi meninggal dunia. Provinsi Jawa Barat menempati urutan kedua kenaikan kasus tertinggi sebesar 137,8\% (707 vs. 1.681) dibandingkan provinsi DKI Jakarta yang menempati urutan pertama kenaikan kasus tertinggi sebesar 36,9\% (4.067 vs. 5.568). Khusus untuk Kabupaten Bandung sendiri berdasarkan data yang didapatkan dari Pusat Informasi \& Koordinasi COVID-19 Gugus Tugas Kabupaten Bandung (2020), jumlah orang yang terkonfirmasi positif COVID-19 hingga akhir Agustus 2020 mencapai lebih dari 400 orang. Desa Bojongsoang menjadi penyumbang kasus terkonfirmasi positif yang cukup banyak hingga mencapai $30 \%$ dari total kasus positif di Kabupaten Bandung pada bulan Agustus 2020. Sehingga, dari data tersebut terlihat bahwa rantai penyebaran virus COVID-19 masih belum sepenuhnya terputus yang terlihat dari bertambahnya jumlah positif COVID-19 khususnya di Kabupaten Bandung dan Provinsi Jawa Barat pada umumnya. Selain itu, pada pertengahan Juni 2020, berdasarkan Peraturan Bupati Bandung Nomor 43 tahun 2020 berlaku kebijakan "Adaptasi Kebiasaan Baru (AKB)" berupa pelaksanaan Pembatasan Sosial Berskala Mikro (PSBM) pasca pelaksanaan Pembatasan Sosial Berskala Besar (PSBB) yang ditetapkan Pemerintah Daerah dan Pemerintah Pusat. Untuk itu diperlukan adanya tambahan sosialisasi dan edukasi kepada masyarakat tentang cara pencegahan virus COVID-19 dan kebijakan AKB tersebut (Irawan et al., 2020; Prayitno et al., 2020; Wikantiyoso et al.,2020).

Berdasarkan hal tersebut, diperlukan upaya dalam menekan penyebaran virus COVID-19. Salah satunya adalah dengan melakukan edukasi dan sosialisasi melalui penyampaian informasi tentang bagaimana cara memulai untuk hidup sehat sehingga terhindar dari virus COVID-19 (Razi et al., 2020; Sufiyanto et al., 2020). Salah satu media edukasi yang dapat digunakan untuk menyampaikan informasi adalah poster yang informatif, animatif, dan mudah dipahami (Zukmadini et al., 2020; Arsyad, 2013). Harapannya, dengan adanya kegiatan ini dapat menjadi pengingat agar masyarakat setiap saat melakukan perilaku hidup bersih sebagai upaya mencegah penyebaran virus COVID-19. Selain itu, pada pelaksanaan kegiatan ini dilakukan survei tingkat kepatuhan masyarakat terutama ketika berada di luar 
rumah. Dengan adanya survei ini, temuan yang didapatkan bisa dijadikan sebagai data awal/informasi untuk masukan bagi pemangku kepentingan setempat dalam upaya menghindari penularan virus COVID-19.

\section{METODE}

Metode pelaksanaan pada kegiatan abdimas ini dibagi dalam tiga tahapan, yaitu pra-kegiatan abdimas, pelaksanaan kegiatan abdimas, dan pasca kegiatan abdimas. Tahap pra-kegiatan abdimas dilakukan dalam bentuk audiensi langsung kepada mitra sasar untuk mengidentifikasikan atau memetakan masalah yang dimiliki atau diperlukan saat ini. Selain itu, hal yang terpenting adalah kesediaan mitra untuk memfasilitasi kegiatan abdimas. Hasil audiensi kemudian ditindaklanjuti oleh tim abdimas untuk mempersiapkan pelaksanaan kegiatan abdimas, termasuk didalamnya persiapan materi dan halhal lainnya.

Tahap berikutnya adalah pelaksanaan kegiatan abdimas. Pada tahap ini, pelaksanaan kegiatan abdimas sesuai dengan hasil audiensi pada tahap pra-kegiatan abdimas. Kegiatan yang dipilih yaitu penyuluhan yang bertujuan meningkatkan pemahaman serta kesadaran akan bahaya COVID-19, media penularan, cara mencegah penularan COVID-19, dan jenis-jenis masker yang efektif dalam menangkal penularan penyebaran virus COVID-19. Pada tahapan ini, materi presentasi abdimas (PowerPoint), poster A3, dan dokumen-dokumen pendukung seperti kuesioner sudah harus siap. Dalam tahapan ini, tim menyiapkan dua jenis kuesioner yaitu evaluasi (kepuasan mitra/masyarakat sasar) terhadap kegiatan abdimas dan kuesioner perilaku masyarakat sasar dalam pencegahan penularan virus COVID-19. Pelaksanaan kegiatan abdimas dalam bentuk penyuluhan ini juga melibatkan kegiatan diskusi dengan peserta tentang permasalahan dalam perilaku masyarakat Desa Bojongsoang terkait pencegahan penularan virus COVID-19, serta berdiskusi untuk mendapatkan solusi dari permasalahan yang dialami.

Tahap terakhir adalah pasca kegiatan abdimas, yang mencakup evaluasi kegiatan terutama selama kegiatan abdimas berlangsung. Pada tahap terakhir ini dilakukan penyebaran kuesioner terkait evaluasi/ penilaian kegiatan abdimas apakah sudah sesuai dengan tujuan dan kebutuhan mitra sasar/masyarakat desa Bojongsoang.

\section{HASIL DAN PEMBAHASAN}

Dalam masa penerapan PSBM tidak memungkinkan adanya sosialisasi dengan cara mengumpulkan massa yang banyak, sehingga bentuk pengabdian masyarakat (abdimas) hanya mengundang perwakilan masyarakat (champions) di Desa Bojongsoang. Terdapat dua jenis poster dengan topik yang berbeda, yaitu poster yang berisi informasi bagaimana berperilaku hidup sehat selama masa pandemi COVID-19 dengan menerapkan protokol kesehatan 3M (mencuci tangan dengan sabun/hand sanitizier, memakai masker, dan menjaga jarak), serta poster yang berisi informasi efektivitas bahan yang digunakan pada masker. Kedua poster tersebut diperuntukkan bagi masyarakat sasaran melalui perwakilan perangkat Kelurahan/Desa Bojongsoang, dan dapat ditempelkan pada instansi-instansi tempat mereka bekerja. Gambar 1 menunjukkan materi poster yang digunakan. 
ABDIMAS: Jurnal Pengabdian Masyarakat Universitas Merdeka Malang Volume 6, No. 2, May 2021: 221-229

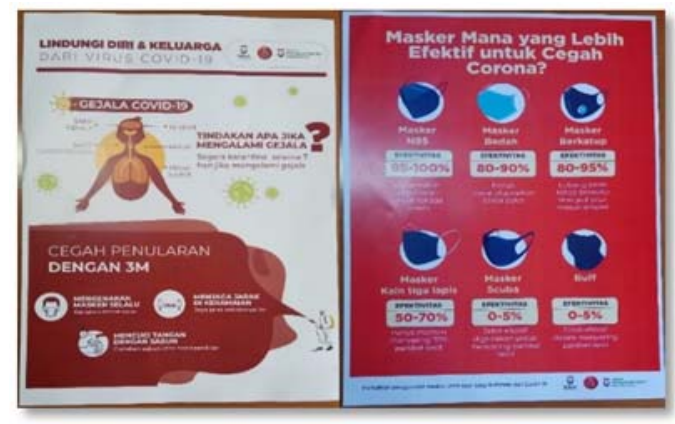

Gambar 1. Desain poster yang digunakan untuk edukasi dan sosialisasi protokol kesehatan pencegahan penularan COVID-19

Kegiatan abdimas ini dilaksanakan pada Rabu, 21 Oktober 2020, pukul 09.00-12.00 WIB, bertempat di Aula Kantor Desa Bojongsoang, Jalan Raya Bojongsoang No. 23, Bandung, 40288. Sebanyak 16 peserta penyuluhan, yang merupakan perwakilan dari Desa Bojongsoang yang terdiri dari aparatur desa, perwakilan Badan Perwakilan Desa (BPD), perwakilan Pos Pelayanan Kesehatan Terpadu (Posyandu), perwakilan Bintara Pembina Desa (Babinsa), dan perwakilan pengurus Rukun Warga (RW) Desa Bojongsoang.

Sebelum kegiatan abdimas berlangsung, tim abdimas membagikan kuesioner untuk mengukur tingkat kepatuhan masyarakat (khususnya perwakilan dari warga yang berada di wilayah Desa Bojongsoang) dalam menjalankan protokol kesehatan ketika berada di luar rumah terutama pada masa pandemi COVID-19. Hasil dari survei ini dapat digunakan sebagai gambaran awal dan kondisi terkini terkait perilaku masyarakat khususnya warga Desa Bojongsoang selama pandemi COVID-19. Akan tetapi perlu diingat bahwa analisis yang dihasilkan merupakan gambaran individu dan tidak mewakili kondisi seluruh warga yang ada di Desa Bojongsoang pada umumnya. Gambar 2 berikut merupakan infografis demografi responden yang mengikuti penyuluhan dan mengisi survei perilaku masyarakat.
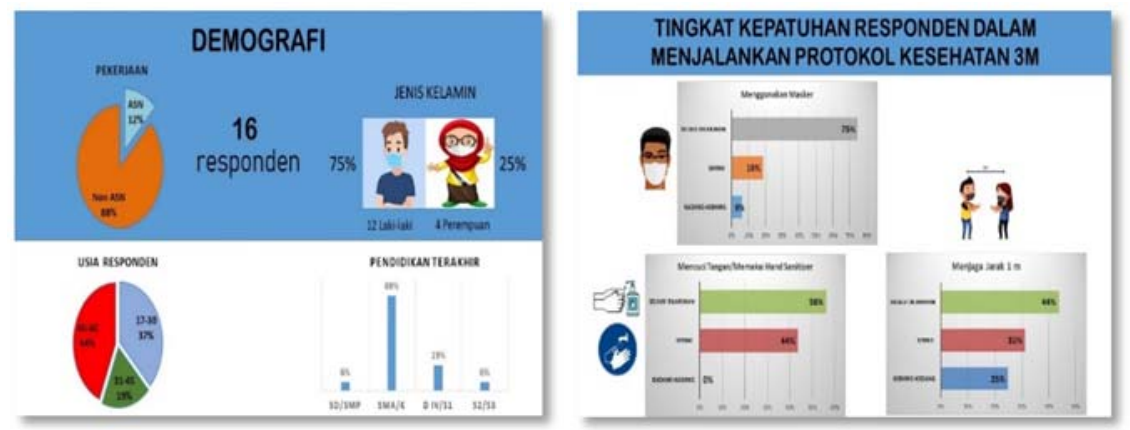

Gambar 2. Infografis demografi responden

Gambar 3. Infografis tingkat kepatuhan responden dalam menjalankan protokol 3M 


\section{Edukasi dan Sosialisasi Pencegahan dan Pengendalian COVID-19 melalui Media Poster di Desa Bojongsoang...}

Dino Caesaron, Sheila Amalia Salma, Murman Dwi Prasetyo, Mohammad Husain Rifai

Dari data tersebut, responden survei 44\% didominasi usia 46-60 tahun, dengan pendidikan tertinggi sebanyak $69 \%$ berijazah SMA/K. Dari 16 responden hanya ada empat responden perempuan (25\%) yang merupakan perwakilan dari Posyandu Desa Bojongsoang. Gambar 3 mencerminkan tingkat kepatuhan responden selama sepekan terakhir terutama saat berada di luar rumah, dalam menjalankan protokol kesehatan 3M.

Dari Gambar 3, tingkat kepatuhan responden dalam menerapkan protokol kesehatan 3M khususnya ketika berada diluar rumah dalam sepekan terakhir sudah baik. Dalam penggunaan masker ketika berada diluar rumah, ada $6 \%$ dari responden yang masih jarang menggunakan masker. Akan tetapi sebagian besar dari responden (75\%) selalu menggunakan masker terutama ketika berada diluar rumah. Hal yang menarik adalah responden lebih sering menerapkan protokol kesehatan mencuci tangan atau menggunakan hand sanitizer ketika berada diluar rumah. Terlihat bahwa tidak ada responden yang menjawab jarang atau kadang-kadang menggunakan hand sanitizer ketika berada diluar rumah. Kemudahan dalam menjalankan protokol tersebut dapat menjadi salah satu alasan kenapa protokol tersebut lebih banyak dilakukan responden ketika berada di luar rumah. Selain itu, kepatuhan dalam menjalankan protokol kesehatan tersebut juga ditunjang dengan kesadaran responden/masyarakat terhadap dampak resiko yang besar (ancaman kematian) dan tingkat pendidikan masyarakat. Untuk protokol kesehatan menjaga jarak minimal 1 meter ketika berinteraksi dengan orang lain menjadi protokol yang paling jarang dilakukan. Sebanyak $25 \%$ responden menjawab kadang-kadang melakukan protokol ini. Hal ini tentunya menjadi catatan tersendiri untuk selalu menjaga jarak terutama ketika berbicara dengan orang lain, terlebih jika orang lain tersebut tidak menggunakan masker ketika berbicara.

Analisis berikutnya yang dimasukkan ke dalam survei kepatuhan adalah persepsi responden terhadap tingkat efektivitas dari protokol kesehatan dan pandangan responden terhadap alasan masyarakat tidak menerapkan protokol kesehatan untuk mencegah penularan virus COVID-19. Dari Gambar 4 terlihat bahwa responden menganggap penggunaan masker dan mencuci tangan memiliki tingkat efektivitas yang relative lebih tinggi dibandingkan protokol kesehatan lainnya (menghindari kerumunan, menjaga jarak $1 \mathrm{~m}$, dan menggunakan hand sanitizer). Selain dari persepsi responden terkait efektivitas protokol kesehatan dalam mencegah infeksi COVID-19, dilakukan juga analisis terhadap alasan masyarakat yang tidak menjalankan protokol kesehatan (menurut persepsi responden kegiatan abdimas). Dari Gambar 4 pula dapat dilihat bahwa lebih dari setengah (56\%) responden beranggapan bahwa perilaku masyarakat yang tak acuh menjadi alasan untuk tidak menerapkan protokol kesehatan. Tentunya dari hasil ini dapat diambil pelajaran berharga bahwa tingkat kepedulian masyarakat terhadap diri sendiri dan orang lain masih rendah. Sehingga perlu adanya pendampingan yang konsisten baik berupa edukasi, sosialisasi pada setiap lini masyarakat, agar penerapan protokol kesehatan dapat merata dan masyarakat dapat merubah perilaku atau pola pikir untuk peduli terhadap kesehatan, paling tidak bagi pribadi dan keluarga. 
ABDIMAS: Jurnal Pengabdian Masyarakat Universitas Merdeka Malang

Volume 6, No. 2, May 2021: 221-229

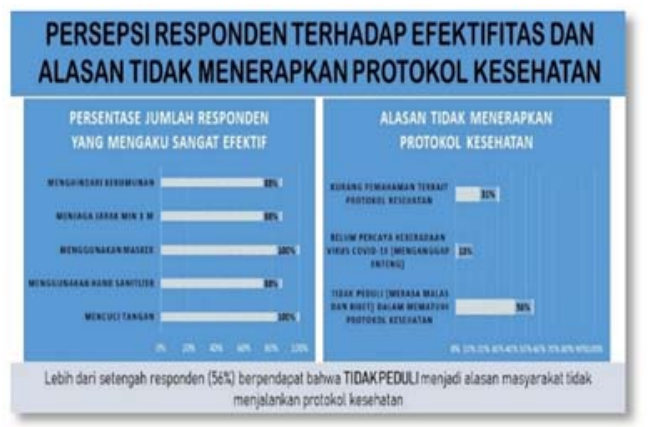

Gambar 4. Grafik persepsi responden terhadap efektivitas dan alasan tidak menerapkan protokol kesehatan untuk pencegahan infeksi COVID-19

Kegiatan diskusi melibatkan peserta, pembicara dari tim abdimas, dan Kepala Desa Bojongsoang Selama pelaksanaan kegiatan abdimas protokol kesehatan dilakukan dengan menjagajarak antar peserta, menggunakan masker dan face-shield selama segiatan berlangsung. Di akhir sesi pelaksanaan kegiatan abdimas ini juga dilakukan bantuan sosial dengan membagikan alat pelindung diri (APD) berupa 50 masker, 50 face-shield, dan 50 hand sanitizer kepada warga yang berada di Kantor Desa Bojongsoang. Pada sela-sela kegiatan berlangsung, perwakilan tim abdimas juga mengambil foto dan video untuk keperluan dokumentasi kegiatan. Gambar 5 menunjukkan foto kegiatan abdimas dan donasi APD yang diserahkan oleh ketua kegiatan abdimas kepada Kepala Desa Bojongsoang.
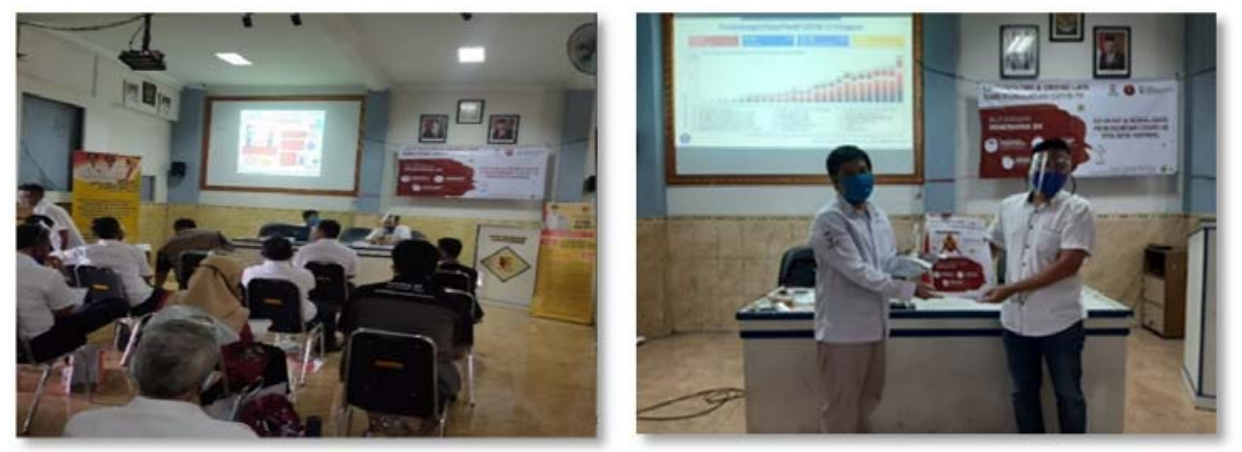

Gambar 5. Perwakilan masyarakat Desa Bojongsoang mengikuti sesi edukasi dan sosialisasi (kiri) dan penyerahan simbolis apd kepada kepala desa (kanan)

Pada kegiatan ini juga dilakukan evaluasi terhadap kegiatan abdimas. Ada beberapa pernyataan yang diajukan terkait pelaksanaan kegiatan. Secara keseluruhan, responden menjawab kegiatan abdimas ini sudah sesuai dengan tujuan kegiatan dan kebutuhan masyarakat sasar. Hasil evaluasi dapat dilihat pada Gambar 6 berikut. 

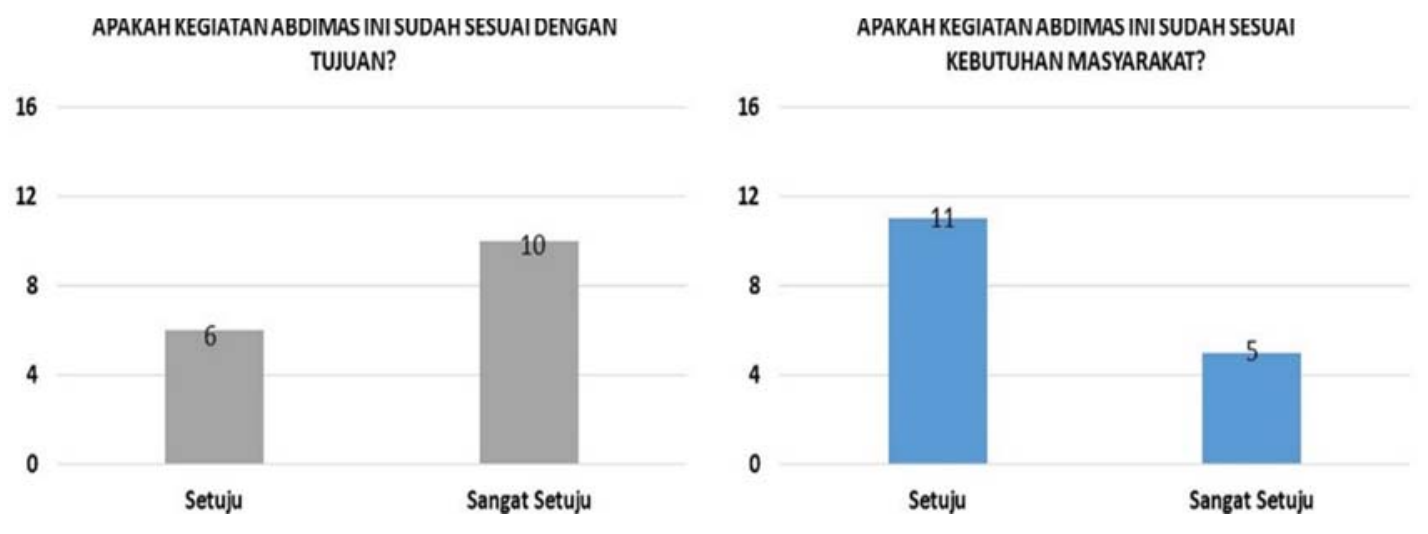

Gambar 6. Grafik evaluasi kegiatan abdimas

Selain itu, responden mengharapkan kegiatan pendampingan kedepannya agar dapat bersama memajukan masyarakat sekitar khususnya masyarakat Desa Bojongsoang.

\section{SIMPULAN DAN SARAN}

Melalui kegiatan abdimas ini, dapat dilihat tingkat kepatuhan masyarakat khususnya Desa Bojongsoang, yang diwakili oleh aparatur desa, penyuluh kesehatan, dan RW, dalam menerapkan protokol kesehatan sebagai langkah pencegahan penularan virus COVID-19. Dari analisis hasil survei yang didapatkan, perwakilan masyarakat relatif sudah menerapkan beberapa protokol kesehatan seperti memakai masker, menggunakan hand sanitizer dan berusaha menjaga jarak $1 \mathrm{~m}$, terutama ketika berada di luar rumah. Dari protokol 3M tersebut, memakai masker dan menggunakan hand sanitizer menjadi protokol yang sering digunakan ketika berada di luar rumah. Sedangkan protokol menjaga jarak $1 \mathrm{~m}$, relatif jarang dilakukan ketika di luar rumah. Melalui kegiatan ini, didapatkan juga persepsi terhadap efektivitas penerapan protokol kesehatan dan alasan kenapa masyarakat cenderung tidak menerapkan protokol kesehatan. Menurut responden, menggunakan masker dan mencuci tangan merupakan protokol kesehatan yang paling efektif dilakukan untuk mencegah infeksi COVID-19 dibandingkan protokol kesehatan lainnya. Responden juga beranggapan bahwa perilaku masyarakat yang tidak peduli/merasa malas/ribet dalam mematuhi protokol kesehatan, menjadi alasan utama tingkat penyebaran COVID-19 masih tinggi. Namun, tentunya hal ini memerlukan analisis lebih lanjut dan penambahan responden yang dapat mewakili masyarakat pada umumnya hingga dapat diambil suatu simpulan terkait perilaku masyarakat Desa Bojongsoang. Kegiatan edukasi dan sosialisasi mengenai upaya pencegahan penularan virus COVID-19 menjadi hal sederhana yang perlu dilakukan secara konsisten, agar dapat membangun kepedulian masyarakat dalam menjaga kesehatan, melakukan pola hidup bersih dan sehat, terutama dalam masa pandemic saat ini. Melalui kegiatan abdimas ini, diharapkan perwakilan masyarakat (aparatur desa, perwakilan RW, Babinsa, dan lain-lain) dapat menjadi role model atau panutan bagi masyarakat awam dalam menerapkan protokol kesehatan pencegahan infeksi virus COVID-19. 
ABDIMAS: Jurnal Pengabdian Masyarakat Universitas Merdeka Malang

Volume 6, No. 2, May 2021: 221-229

Pada kegiatan abdimas ini, belum dilakukan analisis dari dampak penggunaan media poster sebagai media sosialisasi dan edukasi pencegahan penularan COVID-19 serta efektivitas masker yang digunakan. Untuk kegiatan/tahapan selanjutnya, perlu dilakukan pendampingan berupa evaluasi hingga didapatkan hasil analisis dampak penggunaan media poster terhadap pencegahan penularan COVID19.

\section{UCAPAN TERIMA KASIH}

Kegiatan abdimas ini dapat terselenggara dengan baik atas bantuan pihak-pihak diantaranya, Kepala Desa Bojongsoang beserta para jajarannya, Lembaga Penelitian dan Pengabdian Masyrakat (LPPM) Universitas Telkom, dan perwakilan masyarakat Desa Bojongsoang yang berkenan hadir dalam acara ini.

\section{DAFTAR PUSTAKA}

Anhusadar, L. (2020). Persepsi mahasiswa PIAUD terhadap kuliah online di masa pandemi Covid 19. KINDERGARTEN: Journal of Islamic Early Childhood Education, 3(1), 44-58. https://doi.org/http://dx.doi.org/10.24014/kjiece.v3i1.9609

Arsyad, A. (2013). Media Pembelajaran. Jakarta: PT Raja Grafindo Persada.

Evans, M. (2020). COVID-19: what you need to know about coronavirus. Patient. Retrieved from: https://patient.info/news-and-features/covid-19-what-you-need-to-know-about-coronavirus

Gorbalenya, A. E., Baker, S. C., Baric, R. S., de Groot R. J., Drosten, C., Gulyaeva, A. A., Haagmans, B. L., Lauber, C., Leontovich, A. M., Neuman, B. W., Penzar, D., Perlman, S., Poon, L. L. M., Samborskiy, D., Sidorov, I. A., Sola, I., \& Ziebuhr, J. (2020). Severe acute respiratory syndrome-related coronavirus: The species and its viruses, a statement of the Coronavirus Study Group. bioRxiv:: https://doi.org/10.1101/2020.02.07.937862

Huang, C., Wang, Y., Li, X., Ren, L., Zhao, J., ... \& Jin, Q. (2020). Clinical features of patients infected with 2019 novel coronavirus in Wuhan, China. The Lancet, 395(10223), 497-506.

https://doi.org/10.1016/S0140-6736(20)30183-5

Hui, D. S., Azhar, E. I., Madani, T. A., Ntoumi, F., Kock, R., Dar, O., Ippolito, G., Mchugh, T. D., Memish, Z. A., Drosten, C., Zumla, A., \& Petersen, E. (2020). The continuing 2019-nCoV epidemic threat of novel coronaviruses to global health: The latest novel coronavirus outbreak in Wuhan, China. International Journal of Infectious Diseases, 91, 264-266.

https://doi.org/10.1016/j.ijid.2020.01.009

Irawan, D., Triana, N., Suwarni, L., \& Selviana, S. (2020). Edukasi protokol kesehatan dan strategi pemasaran online melalui program kemitraan masyarakat di era pandemi COVID-19. JMM: Jurnal Masyarakat Mandiri, 4(4), 655-662. https://doi.org/10.31764/jmm.v4i4.2636

Peraturan Bupati Bandung Nomor 43 tahun 2020 tentang Penyelenggaraan Pembatasan Sosial Berskala Besar Secara Proporsional sebagai Persiapan Pelaksanaan Adaptasi Kebiasaan Baru untuk Pencegahan dan Pengendalian Corona Virus Disease 2019 Di Kabupaten Bandung.

Prayitno, S. A., Pribadi, H. P., \& Ifadah, R. A. (2020). Peran serta dalam melaksanakan protokol pencegahan penyebaran Corona Virus Disease (COVID-19) pada masyarakat. DedikasiMU (Journal of Community Service), 2(3), 504-510. https://doi.org/10.30587/dedikasimu.v2i3.1657 
Edukasi dan Sosialisasi Pencegahan dan Pengendalian COVID-19 melalui Media Poster di Desa Bojongsoang... Dino Caesaron, Sheila Amalia Salma, Murman Dwi Prasetyo, Mohammad Husain Rifai

Pusat Informasi \& Koordinasi COVID-19. (2020). Retrieved from: https://pikobar.jabarprov.go.id/ (Diakses pada 20 November 2020).

Pusat Informasi \& Koordinasi COVID-19 Kabupaten Bandung. (2020). Retrieved from: https://covid19.bandungkab.go.id/site/index (Diakses pada 20 November 2020).

Razi, F., Yulianty, V., Amani, S. A., \& Fauzia, J. H. (2020). Bunga Rampai COVID-19: Buku Kesehatan Mandiri untuk Sahabat. Depok: PD Prokami.

Satuan Tugas Penanganan COVID-19 Republik Indonesia. (2020). Retrieved from: https://covid19.go.id/ (Diakses pada 20 November 2020).

Singhal, T. (2020). A review of Coronavirus Disease-2019 (COVID-19). The Indian Journal of Pediatrics, 87(4), 281-286. https://doi.org/10.1007/s12098-020-03263-6

Sufiyanto, S., Yuniarti, S., \& Andrijono, D. (2020). Sosialisasi dan edukasi penilaian mandiri terhadap risiko penularan COVID-19 melalui InaRISK Personal. Abdimas: Jurnal Pengabdian Masyarakat Universitas Merdeka Malang, 5(3), 209-219. https://doi.org/10.26905/abdimas.v5i3.5004

Wikantiyoso, R., Cahyaningsih, D. S., Sulaksono, A. G., \& Widayati, S. (2020). Protokol new normal order pasca pandemi COVID-19 dalam pengembangan Kampoeng Boenga Grangsil berbasis masyarakat. Abdimas: Jurnal Pengabdian Masyarakat Universitas Merdeka Malang, 5(3), 181192. https://doi.org/10.26905/abdimas.v5i3.4803

Zimmermann, P., \& Curtis, N. (2020). Coronavirus infections in children including COVID-19: An overview of the epidemiology, clinical features, diagnosis, treatment and prevention options in children. The Pediatric Infectious Disease Journal, 39(5), 355-368.

https://doi.org/10.1097/INF.0000000000002660

Zukmadini, A. Y., Karyadi, B., \& Kasrina, K. (2020). Edukasi Perilaku Hidup Bersih dan Sehat (PHBS) dalam pencegahan COVID-19 kepada anak-anak di panti asuhan. JPMPI: Jurnal Pengabdian Magister Pendidikan IPA, 3(1), 68-76. https://doi.org/10.29303/jpmpi.v3i1.440 